\title{
VULNERABILITY IN THE CHILD DEVELOPMENT: INFLUENCE OF PUBLIC POLICIES AND HEALTH PROGRAMS*
}

\author{
Daniel Ignacio da Silva ${ }^{1}$, Maria de La Ó Ramallo Veríssimo², Verônica de Azevedo Mazza ${ }^{3}$
}

DOI: http://dx.doi.org/10.7322/jhgd.96760

\begin{abstract}
Introduction: vulnerability in child development can defined as the chance or opportunity to the child to suffer losses or delays in their development due to the influence of individual, social, and programmatic factors, which constitute adverse situations. Objective: to characterize the programmatic dimension of vulnerability in child development, according to the nurse at the Family Health Strategy Program. Methods: a qualitative exploratory study, conducted with nurses from units with the Family Health Strategy, in a city of the southern region of Brazil. Data collected by semi-structured interviews and analyzed according to the dialect hermeneutic and analytic matrix of the vulnerability of children in adverse situations for their development. Results: participants were 39 nurses, one from each health unit, who described budgetary, institutional, administrative and care factors that influence the process of health care and relate to the promotion of child development. Even acknowledging improvements in the current scenario of healthcare, they classified such factors as insufficient. Thus, the categories Fragilities in political-programmatic scenario and Gaps in the programmatic-assistance implementation, explain the vulnerability of the child health care in programmatic dimension, which characterizes a potentially injurious situation to the development. Conclusion: The nurses understand that the programmatic dimension of health care shows up as a significant cause of vulnerability in the development of the child.
\end{abstract}

Key words: health vulnerability, child development, public health policy, primary health care, nursing.

\section{INTRODUCTION}

The attention to the health of the child in the world is going through changes, resulting from technical and scientific developments amend the epidemiological profiles and the guidelines of the social and health policies. ${ }^{1}$ Such changes have been directing for the purpose of providing the child care quality, geared to their health needs, which may decrease the rate of morbidity and mortality and collaborate for child development. . $^{2,3}$

In the last two decades, the decline of infant mortality and of children under five has been effecting in the vast majority of countries, and, in these, comes with neonatal mortality as the main component ofinfant mortality ${ }^{3}$, such as noted in Brazil. In this context, two foci may highlighted as priorities for programmatic actions. The first refers to the quality of attention to maternal and child health through the improvement of coverage of prenatal care and the proportion of births assisted by qualified personnel. ${ }^{3}$ The other refers to the improvement of the health of children who survive, which implies ensuring its full growth and development. ${ }^{4-5}$
With regard to child development, the advances made by the Neuroscience, Molecular biology, Epigenetics and the social and behavioral sciences, show that the experiences of the child in their early childhood will influence in their learning, health conditions throughout their life, economic productivity, and capacity in their role as a responsible citizen. ${ }^{4}$

This is because, in the early years of life, it has defined the architecture of the human brain, not only because of a natural process of maturation, but as an intense process of interaction of environmental stimuli with the biological potential of the child. In this phase of life, positive stimuli, benefiting the development and negative stimuli that are damaging, are determinants of development. ${ }^{2,4}$

Therefore, we need to understand the child as subject with social features, needs and peculiar vulnerabilities, given their intense process of development, as well as vulnerabilities arising from the material conditions of life and the care they receive, since these ensure, or no, opportunities for their development ${ }^{5}$.

\footnotetext{
* Extracted from the dissertation: Vulnerability in development of child according to nurse of the family health strategy - Federal University of Paraná (UFPR) 2012.

1 Master's degree in nursing. Graduate program in nursing school of nursing of the University of São Paulo-USP. São Paulo, Brazil.

2 Doctorate in nursing. Department of Maternal Child and Psychiatric Nursing, Nursing School of University of São Paulo (USP). São Paulo, Brazil.

3 Doctorate in Nursing. Graduate Program in Nursing from the UFPR. Curitiba, Paraná, Brazil. Corresponding author: daniel.silva1076@usp.br
}

Suggested citation: Silva DI, et al. Vulnerability in the child development: influence of public policies and health programs. Journal of Human Growth and Development. 25(1): 11-18

Manuscript submitted Oct 22 2014, accepted for publication Dec 192014. 
Studies show that the delay in child development is associated with socioeconomic situations like poverty, low education, poor housing conditions, malnutrition, and lack of access to health and educational resources. ${ }^{6-7}$ Thus, it is justified to say that child development must be a political priority, especially in early childhood, which demands the commitment of the whole society and the development of public policies aimed at settling the iniquities of social determinants and seek to meet the needs of health according to their degree of vulnerability. ${ }^{8-9}$

Vulnerability in the child development may be defined as the chance or opportunity of the child suffer losses or delays in their development due to the influence of factors of individual, social and programmatic order, which constitute adverse situations. ${ }^{9}$

Therefore, this study presupposes that within the programmatic dimension of vulnerability, the child may have difficulties in their development if faults or breaches in public policies and child care programs in Programmatic political scenario. This defined as the political commitment of governments to establish programs of protection and promotion of children's welfare to reduce infant deaths and resolve the inequalities that determine the losses in their development. This scenario determined by the degree of investments that the State provides for the financing of actions of child care. ${ }^{9}$

In addition, the child development influenced by Political and programmatic guidelines and implementation, which are the formats of child care services as to their working process and to their care model, which guide the care of needs. These aspects may described as the implementation of structural health systems strategies, guiding the model health care and the establishment of a new dynamic in the organization of health actions and services. ${ }^{9}$

Being the nurse a professional who acts on children's health care and, in recent years, has been increasing their performance largely thanks to expressive number of these professionals in the Family health strategy (ESF), it is worth questioning how he understands the vulnerability in a child's development in the face of public health programs and policies. This understanding may stimulate the nurse and health team activities less focused on individual accountability of families for an act that also consider the programmatic support as a resource for families in childcare.

Thus, the objective of this research was to characterize the programmatic dimension of vulnerability in child development according to the nurses of the Family health strategy.

\section{METHODS}

Exploratory qualitative research, held in municipal health Units (UMS), with the ESF, sanitary districts located in the city of Curitiba, in southern Brazil, presenting at the same time the results of indicators of Social integration (IIS) and quality of the domicile (IQD) equal to or less than the average of the city ${ }^{4}$, characterized as areas with greater social and epidemiological risk. Such socioeconomic indicators potentially allow the rapprochement with the reality of the social and programmatic vulnerability in the context of child development ${ }^{9}$, which would lead to a greater need for programmatic actions and recognition of the need on the part of professionals.

The study sample was intentional. The subjects of the research were nurses of the UMS 39, which fulfilled the inclusion criteria: Act in teams in the areas of social and epidemiological risk of UMS, and have two full years of operation in the ESF. Were excluded from the sample the nurses that do not fit the criteria of inclusion, and those who were on vacation, sick leave, or resignation.

Were contacted 43 UMS managers for the study, but there was participation of 39 units, as two nurses refused to participate in the survey, one UMS had no nurse crowded in the area of greater social and epidemiological risk, and a UMS had no nurses with more than 2 years of experience in the ESF.

For the recruitment of subjects, the researcher asked to UMS manager to indicate, through the local health planning, the area of your coverage with social and epidemiological risk, as well as the nurses responsible for this territory.

Each nurse contacted by the researcher and invited to participate. The data collection occurred from February to March 2012, through individual semi-structured interviews, which lasted on average 20 minutes. The interviews addressed aspects that hinder the development of the child in his early childhood, child development losses situations experienced by the nurse, and actions to promote children's development practiced by the nurse. The speeches of the nurses recorded, transcribed, analyzed according to the dialectical hermeneutics, and interpreted based on the analytical matrix of child vulnerability to adverse situations for their development. ${ }^{9}$

The data collected by the master student of research, male, which was prepared methodologically to perform the interviews in specific discipline, and had no personal or professional relationship with the subjects of the research. In the presentation of the results, the sentences presented and identified with the abbreviation (E) and numbered sequentially, ensuring the anonymity of respondents.

The study met the national standards of ethics in research involving human subjects and obtained the approval of the Ethics Committee of the health sciences Federal University of Paraná, under registration No. 1170.095.11.6.

\section{RESULTS}

All participants of the survey were stable, statutory servers being 37 female and 2 male, and all had more than two years of experience in the ESF.

This material comes from research that addressed the individual, social, and programmatic 
dimensions of vulnerability in child development. ${ }^{8}$ Although the three are interconnected dimensions, specific analysis of each dimension provides greater insight and understanding of the aspects of vulnerability, which justifies this presentation.

In the programmatic dimension of vulnerability, emerged the categories Fragilities in political-programmatic scenario andGaps in the programmatic-assistance implementation, demonstrating understanding of the nursing staff about various aspects of the child's life context that relate to their development, as described below.

For nurses, there is low investment of the State in social policy, scarcity of intersectoral joints on attention to population, and weaknesses in the infrastructure of the services, which affect negatively on the development of the child. These conceptions originated the category Fragilities in political programmatic scenario, which explains that, although there are several policies in the areas of health and education, their implementation stillrelegated due to no prioritization of investments required by part of the rulers.

Thus, the nurses highlighted the lack of attention to the State's effective health and its determinants, in particular children, and focus on other interests, limiting the scope of the actions taken by health professionals to promote the child's development:

"Change is a long-term work, I think it has to start from the top, Government has to pay more attention to health, more attention to education, people here do our part, we do our part, you know, we take care of the children, we look for them, but I think the Government has to do more, is an entire network". (E34)

"I think the vision of such personnel, managers; they are focused on other things, like in politics. Therefore, if their visions are not extremely focused [is] for the health sector [...] we cannotwork [...] our vision of them differentiated, because they see in a way and we see otherwise. Is the top of the pyramid?" (E39)

"Child development in the region where we operate is harmed, the educational part, the public network does not have a hearty and privileged education." (E7)

The nurse pointed out the scarcity in the joints that intersectoral characterized by the lack of articulation of the health sector to other areas of society as education, social assistance, and other, which might impair the promotion of child development, due to its complexity and diversity of factors that determine:

"I don't know if the city does not have a fee, [...] would have to create partnerships with companies, [...] and we have plans like that, you know, too, and that alone we can't. (E32) "They [other sectors] really were active in participating in these meetings, and we feel supported, and not in the sense that you go to the meeting of the safety net, you have children there who really need to be monitored and the impression that you have where the only organ that exists right now is health."(E8)

"When you, when you care implements makes a historical survey of newborn, that infant, you notice that there are some gaps that cannot be covered, which is beyond our reach [...] We need [...] of a joint action, both municipal managers, as the area of health, education and security area ". (E16)

Even in this category, the nurse reports weaknesses in the infrastructure of the services, which characterized by a lack of human resources and their capacity building, and by insufficient structure of health establishments:

"I would like to make educational toy shop with them but, hence, how am I going to do if educational toy workshop here my colleague's killing himself in an emergency, the other given a row of thirty patients?(E17) "But we have the problem when talking on the whole; we have a team that never was complete, no doctor, no nurse, [...] a more difficult situation. (E23)

"The post here, we have a very small structure, I think you should have noticed and today you came at a time that is quiet even on Friday, but this morning this is insane, we can't do anything, because that's a lot of people [...] You can't even provide a service, education in here, because of the lack of structure also." (E38)

Additionally, to nurses, the health system hasn't been able to implement programmatic actions for attention and child protection, as well as the care model has been marked by the absence of integral care to their. These characteristics formed the category Gaps in the programmatic-assistance implementation. It defined as gaps, because, although there are policies and programs for the promotion of child development, these have not implemented in the daily nursing assistance, what childcare has become a challenge for teams, as described in the lines:

"If we had done this earlier capture, if we had gotten this pregnant woman before, if we had been able to link it in the prenatal, insert it in a social program, as an independent case, trying to get her off drugs, before this baby comes and there had been discovered this disease." (E1)

"We don't have a program of child still functioning ' in ' Secretariat [...] I think that the Secretariat, as a matter of fact, she cares too much with children up to one year of age [...] but the children after a year they kind of dropped. Think the Secretariat should invest more in children up to five years at least. " (E26) In other words, nurses report that childcare has marked by a lack of equity, characterized by the absence of active listening in their working process:

"I'm looking for better care, hear them[the relatives of the child], we also have to listen to them, their dreams [...] sometimes they come here for a reason, so angry, we send away, don't look right". (E15) 
"Why that's patient with dysuria, always you give antibiotics, it's no use, has to investigate, does it have basic sanitation at home? [...] does this child lives with anemia, because she has proper nutrition? [...] for you to do collective health, you have to put yourself in the place of another ". (E30)

The nurse also highlights the lack of integrality, signaled by the absence of child's access to resources and technologies that could benefit their health and development: "Because it takes a long time, a child who needs phono [audiologist], needs of ophthalmologist, ENT needs [laryngologist], are very difficult, experts that we don't have in the area, is too complicated we get in line and wait a year a child of this for development, and is usually a year or two years to get a specialized query ". (E2)

"This demand we have repressed, consumes us in here that demand that I already told you that is curative, which wants the doctor to wait yesterday, that we don't work promotion and prevention."(E38)

\section{DISCUSSION}

The category Fragilities in politicalprogrammatic scenario refers to low spending on social policies such as health and education that has been a consequence of centralization and political insulation control of macroeconomic policy, particularly with regard to decisions relating to public spending and monetary policy, with subordination of social policies to these dictates, because a predominantly neoliberal ideology and market. ${ }^{10}$

The nurse points to a contradiction present in the life of a Brazilian citizen, who possesses a legally State promoter of social equity, and that however if shows fragile in fulfilling its responsibilities in executing properly health policies, education, public safety, sanitation, housing and public transport. As well as, does not guarantee the budget to fulfill its commitments with the governmental social protection policy. ${ }^{10}$

This situation indicates that the simple provision of medical services and products is not sufficient to protect the health of the population, and this be guaranteed by economic and social policies and by equal and universal access to actions and services for the promotion, protection and recovery of health. ${ }^{11}$

It is worth noting that Brazil, despite having a universal health system, is one of the emerging countries that spend less on health, which is incoherent. In the year 2010, the Brazilian health spending amounted to 7 percent of gross domestic product (GDP) (being 58\% 42\% private spending public spending). Compared with other emerging nations as China and South Africa (12\%) and Indonesia ( $8 \%$ ) spend more on health than Brazil, leaving only India (4\%), with minor investment sector. ${ }^{12}$

Although the nurse have identified in your lines, the fragilities and shortcomings of the government in meeting the needs of the child and family, he does not mention that these are related to the macroeconomic adjustments and reform of the Brazilian State, which introduced the low spending on social policies and prioritization of primary surplus and payment of public debt interest. ${ }^{10}$

The lines concerning the lack of intersectoral approach refer to the ineffectiveness of intersectoral actions in affect the health care of the child. Although the intersectoral approach has been justified and implemented in decrees and regulations, has not yet been possible to an articulation of different sectors and areas of knowledge that take responsibility for early childhood development and ensure integrality in the care of the child. Such State policy should be a platform for government support and articulate to promote the well-being of the people and the community. ${ }^{5}$

It's possible glimpse in the results that the nurse understands the care for child development as project that demands intersectoral action, involving various organs of civil society and the State in solving the problems of the child. This vision of careful search to overcome the notion of health as exclusive assignmentof health sector and refers to intersectoral action from social policies and of popular participation in the decision-making process on the actions of individual and collective health. ${ }^{13}$

Even in this category, the nurse relates the weaknesses in the infrastructure of the services with the situation of precariousness and scrapping of the public service. This reality may be see in a large number of services in Brazil. Although the Sistema Único de Saúde (SUS which is the National Health System) has been advances within the legal and policy perspective, one should consider that the 'macro politics' reforms of the State, that occurred in the $1990^{10}$, influenced in a manner relevant to health policy and its guidelines for the hiring and training of human resources. During this period, many advances and setbacks in the area of human resources in health were arising from the clash between the theoretical-conceptual elements and ideological-political reform project with the needs of the SUS implementation. ${ }^{14}$

Although Brazil is with above-average number of professionals from developing countries, ${ }^{15}$ human resources are not distributed in an equitable manner throughout the national territory, and there is still lack of professionals in many regions (North and Northeast), and concentration of manpower in more developed regions (East and South), where wages and working conditions are more attractive. ${ }^{16}$ Even in these regions also have difficulty in allocating human resources in more peripheral locations of large capitals, as the city of Curitiba, where the study was done.

Additionally, the nurse refers to the precariousness of the physical structure of many health equipment. There are many problems within those institutions, since the real estate property, the lack of legalization of land and the lack of physical space for the implementation of all actions. ${ }^{16}$ Despite the investments made in reform 
and expansion of health equipment, in town to study*, the structuring of health units still conforms as a major obstacle to the improvement of health care, and most municipalities do not have sufficient resources for the implementation of these projects. ${ }^{17}$

Thus, itunderstood that the weaknesses in the political-programmatic scenario cause the inefficiency of policies and programs for early childhood and harm the child needs care and the promotion of their development. $1,4,5,9$

Figure 1 presents, for better understanding of the reader, the explanatory synthesis on this category of programmatic vulnerability in the child's development, according to the Nurses of the ESF, composed by empirical categories of analysis, its related aspects and contradictions and implications for child development:
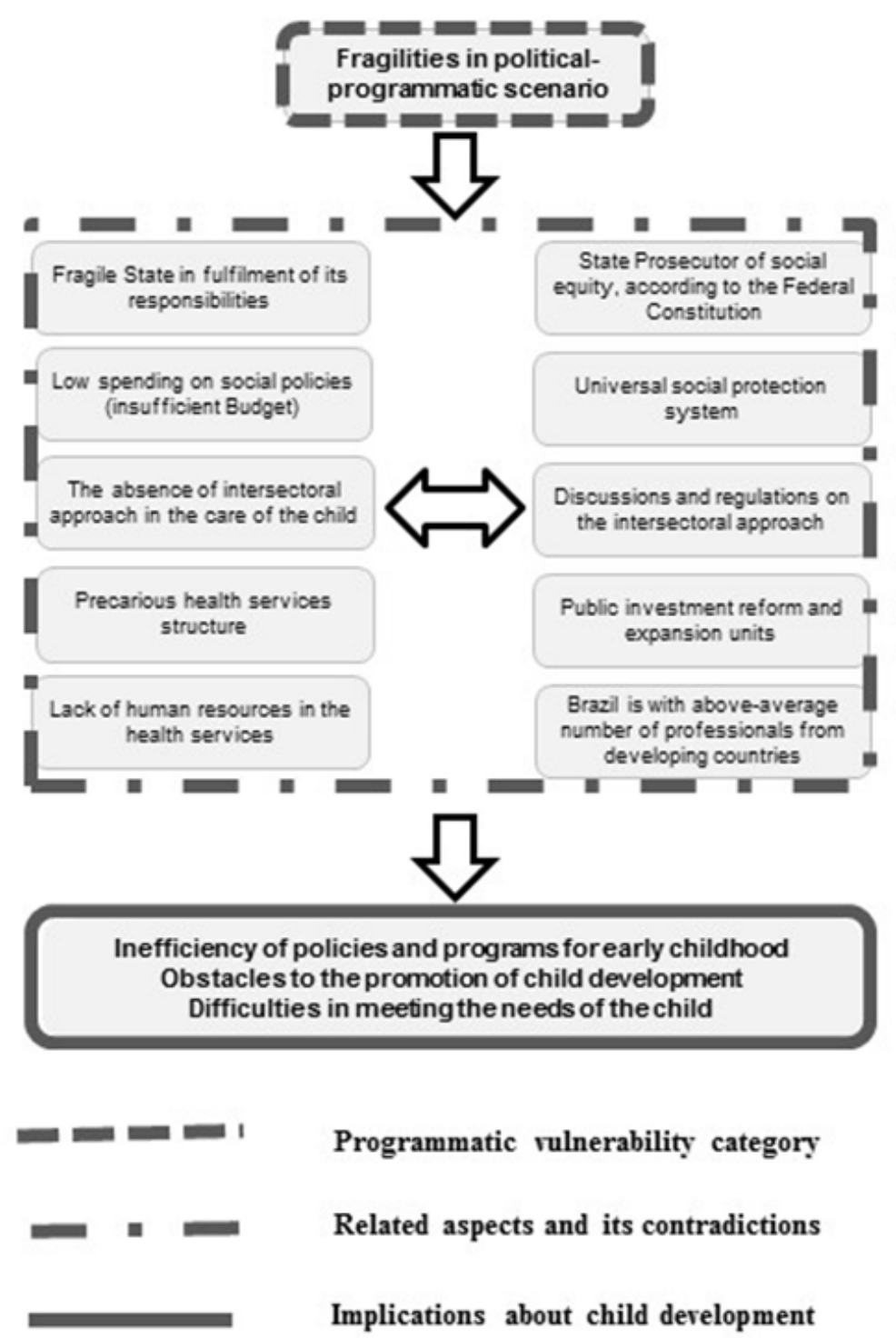

Figure 1 - Fragilities in political-programmatic scenario and its implications in the child's development, according to the nurses of the ESF. Curitiba 2012

The category Gaps in the program-maticassistance implementation points to capture failures of pregnant women due to early initiation of prenatal care. The effectiveness of prenatal care allows access of pregnant women to diagnostic and therapeutic methods for various diseases, as well as the monitoring of fetal growth and complications, adding more security for the mother and the child. ${ }^{18,19}$
This speech confirms that, despite the improvements of the indicators of prenatal care in Brazil, although it appears that some local health systems fail in implementing the actions of prenatal, low number of queries, the late women's capture, for non-routine tests and request for non-gestational risk stratification. ${ }^{20}$

The lines of the nurses oppose the reality of prenatal care in town in study that, historically, has

\footnotetext{
* Reforms and constructions of equipment in primary health care in accordance with Ordinance No. 1,241/GM/MS, of June 6, 2014 and other publications of the Ministry of health.
} 
had a significant role in prenatal care with the implementation of care protocols since 1979. The years 2000 onwards, the Municipal Health Secretariat has implemented the program Mãe Curitibana (Mother of Curitiba), which has shown significant results in prenatal coverage. A study showed that more than $86 \%$ of pregnant women began prenatal care in the first trimester, and over $84 \%$ of pregnant women have conducted the appropriate number of queries and prenatal examinations. ${ }^{21}$

The municipality studied have implemented childcare programs and presents low infant mortality indicators, ${ }^{5}$ however, the nurse recognizes that there are inadequacies in the programs, since they centered in the first two years of life. Before this, the nurse points to the unsatisfactory situation of investments to meet the health needs throughout the period of childhood, although many studies unambiguously demonstrate the importance of attention in the early years of life. ${ }^{4}$ There is evidence that living conditions, opportunities and existing disparities between different socioeconomic groups, influence the development of children as well as their access to can hamper actions and health services. 5
It is understood that the age limit for the more systematic assistance to children in the SUS everywhere should be extended throughout the early childhood (until 6 years), in order to monitor and evaluate the development and carry out necessary interventions for the promotion of child health. 6,9

The data are in agreement with studies that show that, within the context of child health and child development, to achieve satisfactory results, assistance models are needed that aim to ensure the attendance of the child at the primary level of attention, systematize and integrate clinical care curative actions with preventative measures and health promotion ${ }^{22}$, as well as, the due recognition of their needs and demands. ${ }^{23}$

The nurse alludes to equity, within the perspective of active listening to the needs of users in the health units. This process of work is necessary on primary health care, whereas those services should organized in a way unique and appropriate, recombine, rearrange and reorder existing features to meet health needs and demands of the population. ${ }^{24}$

The lines show that the lack of equity still prevails in many health services, although fairness
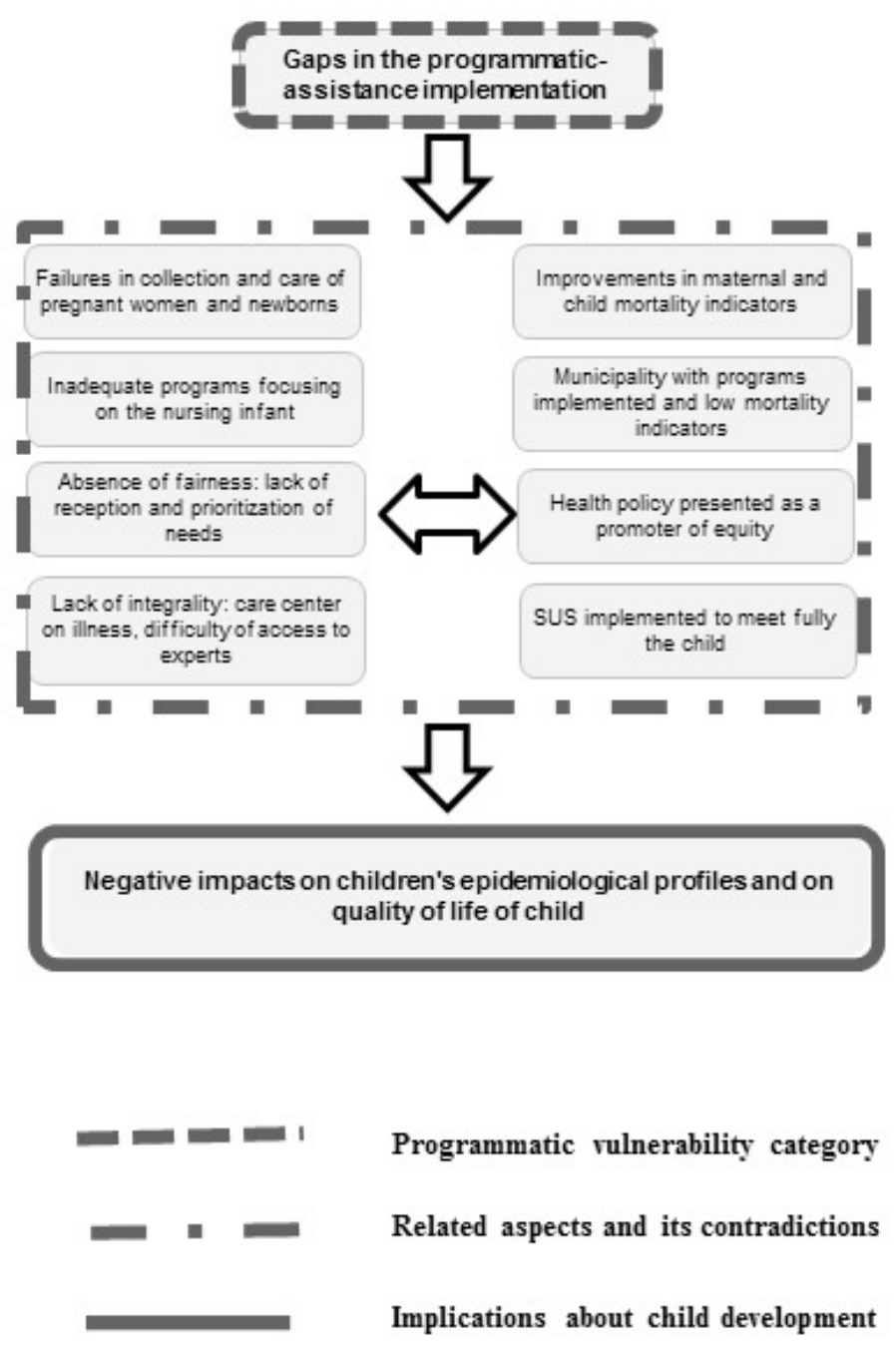

Figure 2 - Gaps in the programmatic-assistance implementation and its implications in the child's development, according to the nurses of the ESF. Curitiba 2012 
provided for in the legal body of the SUS. Such a situation shows that active listening and welcoming to child and their families must carried out by the team of health, within a perspective that ensures continuity and coordination of care. Moreover, this change in the model must produce the bond between professionals and users through a welcoming posture and humanist, guaranteeing the rights of both the child and their families. ${ }^{24}$

However, in primary care services, instead of a welcoming posture, there are professionals, which assistance activities are directed to the disease and not for humans; not for the quality of care, but for procedures performed. This has hindered the formation of ties in the actions. ${ }^{25}$ This occurs, among other factors, by the fact that the evaluations and requirements of administrators of municipalities focus on numerical measurement of the actions.

To point out the lack of integrality, the nurse indicates the need of programs on maternal and child needs, through the reorganization of primary care and the reformulation of the hegemonic and biomedical care model. ${ }^{26-27}$ Integrality is considered as the right that population must be met on the set of their needs, and the duty that public authorities have to offer health services organized to meet these needs in accordance with their clinical and epidemiological profile. ${ }^{22}$

Although the SUS is implemented to meet fully the needs of children coming from any levels of complexity of the system, it should be noted that many health actions are still distant for user access, as was quoted; specialties that should be available, demand is expected to more than a year, causing losses in their state of health. ${ }^{22}$ Instead of an integral

\section{REFERENCES}

1. AJ Barros, C Ronsmans, $\mathrm{H}$ Axelson, Loaiza $\mathrm{E}$, Bertoldi AD, França GVA, et al. Equity in maternal, newborn, and child health interventions in Countdown to 2015: a retrospective review of survey data from 54 countries. Lancet. 2012; 379 (9822): 1225-33. Doi: http://dx.doi.org/10.1016/S0140-6736 (12)60113-5.

2. Shonkoff JP, Garner AS, Committee on Psychosocial Aspects of Child and Family Health, Committee on Early Childhood, Adoption, and Dependent Care, Section on Developmental and Behavioral Pediatrics. The Lifelong Effects of Early Childhood Adversity and Toxic Stress. Pediatrics. $2012 ; 129(1)$ : 232-46. Doi: http:// dx.doi.org/10.1542/Peds.2011-2663.

3. Atrash HK. Childhood Mortality. Still a global priority. J Hum Growth Dev. 2013; 23(3): 257-260.

4. Shonkoff JP. Protecting brains, not simply stimulating minds. Science. 2011; 333(6045): 982-83. Doi: http://dx.doi.org/10.1126/ Science 1206014.

5. Mazza VA, Chiesa AM. Family needs on child development in the light of health promotion. care provided in the unit, the team still experiencing a situation of dichotomy between preventive and curative actions, individual and collective, and without, in most cases, actions that aim to satisfy fully the requirements related to the promotion and restoration of health. 22

Such shortcomings of programmatic implementation may bring negative impacts on child's epidemiological profiles and on quality of life of child, as well as harm the disease prevention to child's health and the promotion of their development. 5,9,22

Figure 2 presents, for better understanding of the reader, the explanatory synthesis on this category of programmatic vulnerability in the child's development, according to the nurses of the ESF, composed by empirical categories of analysis, its related aspects and contradictions and implications for child development:

Thus, according to the professional nurse of the Family health strategy, budget issues, institutional, administrative and welfare characterize the programmatic vulnerability in the development of the child. For the subject, health systems have difficulty in ensuring health care and actions for the promotion of child development, failing to meet adequately the needs of the child.

Given that nurses have shown to be sensitive to aspects that affect development, which correspond to the theoretical model of the analytical matrix of vulnerability, it believed that new studies aimed at designing strategies for identification of adverse situations to child development might bring greater support to health practices in the promotion of development.

Online Braz J Nurs. 2008; 7(3). Doi: http:// dx.doi.org/10.5935/1676-4285.20081852.

6. Victora CG, Hallal PC, Araújo CL, Menezes AM, Wells JC, Barros FC. Cohort profile: the 1993 Pelotas (Brazil) birth cohort study. Int J Epidemiol. 2008; 37(4): 704-709. Doi: http:// dx.doi.org/10.1093/ije/dym177.

7. Martorell R, Nguyen P. Interrelationship between growth and development in low and middle-income countries. Nestle Nutr Workshop Ser Pediatr Program. 2010; 65: 99-118. Doi: http://dx.doi.org/10.1159/000281151.

8. Pedroso MLR, Motta MGC. A compreensão das vulnerabilidades socioeconômicas no cenário da assistência de Enfermagem pediátrica. Rev Gaúcha Enferm. 2010; 31(2): 218-24. Doi: htt p: / / dx.doi.org/10.1590/S198314472010000200003.

9. Silva DI, Chiesa AM, Veríssimo MLOR, Mazza VA. Vulnerability of children in adverse situations to their development: proposed analytical matrix. Rev Esc Enferm USP. 2013; 47(6):1397-402. Doi: http://dx.doi.org/ 10.1590/S0080-623420130000600021.

10. Cherchiglia ML, Dallari SG. A reforma do Estado e o setor público de saúde: governança e eficiência. Rev Adm Pública. 1999; 33(5): 65-84. 
11. Feuerwerker LM. Modelos tecnoassistenciais, gestão e organização do trabalho em saúde: nada é indiferente no processo de luta para a consolidação do SUS. Comunic Saúde Educ. 2005; 9 (18): 489-506.

12. Countdown Coverage Writing Group, Countdown to 2015 Core Group, Bryce J, Daelmans B, Dwivedi A, Fauveau V, et al. Countdown to 2015 for maternal, newborn, and child survival: the 2008 report on tracking coverage of interventions. Lancet. 2008; 371(9620): 1247-1258. Doi: http://dx.doi.org/ 1010.1016/S0140-6736(08)60559-0.

13. Sousa FGM, Erdmann AL, Mochel EG. Modelando a integralidade do cuidado à criança na Atenção Básica de Saúde. Rev Gaúcha Enferm. 2010; 31(4):701-07. Doi: http:// dx. do i . org/10.1590/S198314472010000400013 .

14. Pierantoni CR. As reformas do Estado, da saúde e recursos humanos: limites e possibilidades. Cienc Saúde Coletiva. 2001; 6(2):341-360. Doi: http://dx.doi.org/10.1590/S141381232001000200006 .

15. Gupta N, Maliqi B, Franca A, Nyonator F, Pate $M$, Sanders $D$, et al. Human resources for maternal, newborn and child health: from measurement and planning to performance for improved health outcomes. Hum Resour Health. 2011; 9(1): 16. Doi: http://dx.doi.org/ 10.1186/1478-4491-9-16.

16. Vianna SM, Nunes A, Santos JRS, Barata RB. Medindo a desigualdade em saúde no Brasil: uma proposta de monitoramento. OPS/IPEA; 2001.

17. Nascimento APS, Santos LF, Carnut L. Atenção primária à saúde via estratégia saúde da família no Sistema Único de Saúde: introdução aos problemas inerentes à operacionalização de suas ações. J Manag Prim Health Care. 2011; 2(1): 18-24.

18. Rosskam E, Pariyo G, Hounton S, Aiga H. Increasing skilled birth attendance through midwifery workforce management. Int J Health Plann Manage. 2013; 28(1): e62-e71. DOI: 10.1002/hpm.2131

19. Rosskam E, Pariyo G, Hounton S, Aiga H. Increasing skilled birth attendance through midwifery workforce management. Int J Health
Plan. Mgmt. 2013; 28: e62-e71. DOI: 10.1002/ hpm. 2131

20. Domingues RMSM, Hartz ZMA, Dias MAB, Leal MC. Avaliação da adequação da assistência prénatal na rede SUS do Município do Rio de Janeiro, Brasil. Cad Saúde Pública. 2012; 28(3): 425-37. Doi: http://dx.doi.org/10.1590/ S0102-311X2012000300003.

21. Uchimura LYT, Uchimura NS, Santana RG, Felchner PCZ, Uchimura TT. Adequabilidade da assistência ao pré-natal em duas unidades de saúde em Curitiba, Paraná. Cienc Cuid Saúde. 2014; 13(2): 219-27. Doi: http://dx.doi.org/ 10.4025/cienccuidsaude.v13i2.21256.

22. Atrash HK, Carpentier R. The evolving role of public health in the delivery health care. J Hum Growth Dev. 2012; 22(3): 396-399.

23. Wong ST, Lynam MJ, Khan KB, Scott L, Loock C. The social pediatrics initiative: A richer model of primary health care for children at risk and their families. BMC Pediatrics. 2012; 12 : 158.Doi: http://dx.doi.org/10.1186/14712431-12-158.

24. Oliveira BRG, Viera CS, Collet N, Lima RAG. Acesso de primeiro contato na atenção primária em saúde para crianças. Rev RENE. 2012; 13(2): 332-42.

25. Bhutta ZA, Ali S, Cousens S, Ali TM, Haider BA, Rizvi $A$, et al. Interventions to address maternal, newborn, and child survival: what difference can integrated primary health care strategies make? Lancet. 2008; 372(9642): 972-89.Doi: http://dx.doi.org/10.1016/S01406736(08)61407-5.

26. Ribeiro LCC, Rocha RL, Ramos-Jorge ML. Acolhimento às crianças na atenção primária à saúde: um estudo sobre a postura dos profissionais das equipes de saúde da família. Cad Saúde Pública. 2010; 26(12): 2316-2322. Doi: http://dx.doi.org/10.1590/S0102311X2010001200010.

27. Costa GD, Cotta RMM, Reis JR, Siqueira-Batista $\mathrm{R}$, Gomes AP, Franceschini SCC. Avaliação do cuidado à saúde da gestante no contexto do Programa Saúde da Família. Ciênc Saúde Coletiva. 2011; 14(5): 1347-57. Doi: http:// dx.do i.org/10.1590/S 1413 81232009000800007 .

\section{Resumo:}

Introdução: vulnerabilidade no desenvolvimento da criança pode ser definida como a chance ou oportunidade de a criança sofrer prejuízos ou atrasos em seu desenvolvimento devido à influência de fatores de ordem individual, social e programática, os quais se constituem em situações adversas. Objetivo: Caracterizar a dimensão programática da vulnerabilidade no desenvolvimento da criança, segundo o enfermeiro da Estratégia Saúde da Família. Método: pesquisa exploratória qualitativa, realizada com enfermeiros de Unidades com Estratégia Saúde da Família, em município da região sul do Brasil. Dados coletados por entrevista semiestruturada e analisados segundo a hermenêutica dialética e a matriz analítica da vulnerabilidade da criança diante de situações adversas ao seu desenvolvimento. Resultados: participaram 39 enfermeiros, um de cada unidade de saúde, os quais descreveram fatores orçamentários, institucionais, administrativos e assistenciais que influenciam o processo de cuidado em saúde e se relacionam à promoção do desenvolvimento infantil. Mesmo reconhecendo melhorias no cenário atual da assistência, eles classificaram tais fatores como insuficientes. Assim, as categorias Fragilidades no cenário político-programático e Lacunas na implementação programático-assistencial explicam a vulnerabilidade da atenção à saúde da criança na dimensão programática, o que caracteriza uma situação potencial de prejuízo a seu desenvolvimento. Conclusão: os enfermeiros compreendem que a dimensão programática da atenção à saúde mostra-se uma relevante causa da vulnerabilidade no desenvolvimento da criançaça.

Palavras-chave: vulnerabilidade em saúde, desenvolvimento infantil, políticas públicas de saúde, atenção primária à saúde, enfermagem. 